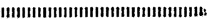

技術報告

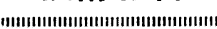

UDC $621.774 .21: 621.791 .754: 621.791 .753 .5$

\title{
厚肉 $\mathrm{UOE}$ 鋼管製造のための大電流 $\mathrm{MIG}+$ タンデムサブ
}

\section{マージアーク溶接法の開発}

\author{
平林清照* . 平 忠明 ${ }^{* 2} \cdot$ 市之瀬弘之 ${ }^{* 3} \cdot$ 平野 攻*4 \\ Development of High Current $\mathrm{MIG}+2 \mathrm{SAW}$ Technique for Heavy \\ Wall UOE Linepipes
}

Kiyoteru Hirabayashi, Tadaaki TaIra, Hiroyuki Ichinose, and Osamu Hirano

Synopsis :

MIG +2SAW technique has been developed for longitudinal welding process to produce the heavy wall UOE linepipes up to $50 \mathrm{~mm}$ in thickness.

(1) An experimented MIG + 2SAW equipment is designed so that the leading electrode is DCRP for high current MIG welding and the middle and trailing electrodes are connected in Scott transformer connection for 2SAW. This equipment placing MIG and 2SAW torches on one cart can weld test plates with one-run. The arc interaction between MIG and 2SAW has hardly been observed.

(2) MIG +2SAW process is devised to disperse the heat input to decrease it per one molten pool as compared with 3SAW because a torch spacing between MIG and 2SAW is long enough and two molten pools are formed. Therefore weld metal and HAZ in the center of plate thickness by MIG + 2SAW process give a better toughness than those by 3SAW.

(3) As the heat input of 2SAW on MIG + 2SAW process can be lowered as compared with that of 3SAW, MIG + 2SAW process consumes a fewer fluxes than 3SAW. The shielding effect of the molten slag is scarcely deteriorated because it is not overheated even if the fused flux is used. As a result the weld bead in $50 \mathrm{~mm}$ thickness plate is sound and slippery.

\section{1. 緒言}

UOE 鋼管の需要は今後厚肉化の傾向にあるために,き わめて能率の高い 3 電極サブマージアーク溶接 (3SAW) を厚肉鋼管に適用するのが本来は好都合である. しかし 現状の溶融型フラックスを用いた $3 \mathrm{SAW}$ の場合, 板厚 $40 \mathrm{~mm}$ 以下は両面 1 層溶接が良好であるが，それ以上の 板厚に括いては, フラックスの高温に抢ける粘性と融点 が問題となつて，ビード形状が劣化し，溶接電流に限界 を与觉ることをすでに明らかにした1)。また大入熱の 3SAWでもつて厚肉鋼管を溶接した場合，溶接部の靸性

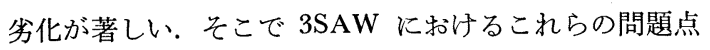
を解決するものとして，溶接プロセスの面から大電流
$\mathrm{MlG}+2 \mathrm{SAW}$ 法について検討を行い，良好な継手を得 る方法を確立した，一方，高木 ${ }^{2}$ は小電流細径の $\mathrm{CO}_{2}$ 溶 接と単電極 $\mathrm{SAW}$ を組み合わせた溶接法について報告し ているが，この方法は SSAW に比べて溶着量が少なく, 板厚 $50 \mathrm{~mm}$ の厚肉鋼管を両面 1 層溶接できなかつた. また藤森ら゙) は細径ワイヤを用いた大電流密度の MIG 溶接法と SAW 法を組み合わせた溶接法について報告し ているが，管厚 $50 \mathrm{~mm}$ までの厚肉鋼管の溶接を対象と した報告ではなく，上垣ら）は $44 \mathrm{~mm}$ 厚の厚肉鋼管を 対象に大電流 MIG+SAW 溶接法について報告してい るが，この場合の大電流 MIG トーチと SAW トーチは 同時に 1 ラン溶接することのできる機構ではなかつた. 一方，TANAKA ら5) は大電流 MIG を単独またはタンデ

昭和 54 年 4 月本会講演大会にて発表 昭和 55 年 10 月 22 日受付 (Received Oct. 22, 1980)

* 日本鋼管(株)技術研究所福山研究所 (Fukuyama Laboratories, Technical Research Center, Nippon Kokan K.K., 1 Kokan-cho Fukuyama 721)

*2 日本鋼管(株)技術研究所福山研究所工博 (Fukuyama Loboratories, Technical Research Center, Nippon Kokan K.K.)

*3 日本鋼管 (株) 技術研究所福山研究所 Ph. D (Fukuyama Laboratories, Technical Research Center, Nippon Kokan K.K.)

*4 日本鋼管 (株) 福山製鉄所 (Fukuyama Works, Nippon Kokan K.K.) 
ム MIG(2MIG) で用いる方法をすでに開発している. 本研究の MIG + $2 \mathrm{SAW}$ 法はL極で大電流 MIG 溶接を 行い, M極とT極をスコット結線にしたタンデム SAW (2SAW) を組み合わせて，1 ランで溶接する方法であ り, MIG と $2 \mathrm{SAW}$ の極間距離を約 $350 \mathrm{~mm}$ 以上離して いるために，2溶融池になつている．大電流 MIG 溶接

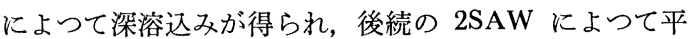
滑なビード外観が得られる．かつ本方法は溶接する時の 溶接入熱を分散できるので高鞋性が要求されるラインパ イプの溶接に適した方法である. 今回, 板厚 $38 \mathrm{~mm}$ と $50 \mathrm{~mm}$ の鋼板を使用した厚肉鋼管の製造のために, MIG +2SAW 法による両面 1 層溶接継手の性能を，従来の 3SAW，2SAW と比較した結果及び一部は管厚 $38 \mathrm{~mm}$ の鋼管をタンデム $\mathrm{MIG}(2 \mathrm{MIG})+\mathrm{SAW}$ 溶接した結果 についてもあわせて報告する.

\section{2. 実 験 方 法}

本研究では, 板厚 $38 \mathrm{~mm}$ と $50 \mathrm{~mm}$ の鋼板と鋼管を 用いた，各供試鋼板と鋼管のグレードおよび適用した溶 接プロセスの関係を Table 1 に示す. サンプル No. A と $\mathrm{G}$ は $\mathrm{Mn}-\mathrm{Nb}-\mathrm{V}$ 系成分を $38 \mathrm{~mm}$ と $50 \mathrm{~mm}$ に圧延 した鋼板で $\mathrm{MIG}+2 \mathrm{SAW}$ 溶接と $3 \mathrm{SAW}$ の溶接試験を した、BとDはグレード 5LB であり，実管を試作し， $\mathrm{B}$ は $2 \mathrm{MIG}+\mathrm{SAW}$ と $3 \mathrm{SAW}$ 法でDは $3 \mathrm{SAW}$ で溶接 をした．板厚 $38 \mathrm{~mm}$ と $50 \mathrm{~mm}$ 鋼板の $\mathrm{MIG}+2 \mathrm{SAW}$ 法と 3SAW の溶接条件を Table 2 に示す. 板厚 38 $\mathrm{mm}$ の鋼板を $3 \mathrm{SAW}$ した場合の溶接入熱は $122.5 \mathrm{~kJ} /$ $\mathrm{cm}$ であるのに対して, MIG+2SAW 法は (33.1+83.8) $\mathrm{kJ} / \mathrm{cm}$ である.板厚 $50 \mathrm{~mm}$ の場合の $3 \mathrm{SAW}$ の溶接入 熱は $224.5 \mathrm{~kJ} / \mathrm{cm}$ であるのに対して，MIG+2SAW 法 は $(55.1+150.8) \mathrm{kJ} / \mathrm{cm}$ である. $\mathrm{MIG}+2 \mathrm{SAW}$ 法は MIG と $2 \mathrm{SAW}$ の 2 溶融地になつており, 入熱の分散化

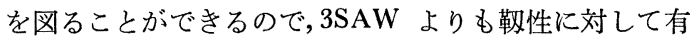
利である，供試溶接ワイヤは MIG と SAW ともに, 同 一成分の C-Si-Mn-Ni-Mo-Ti 系の $4.8 \phi$ のワイヤ $\mathrm{A}$ を用いた. 供試フラックスは溶融型を用い，(a)塩基度6)
$\mathrm{BL}_{\mathrm{L}}=-0.45$ の含 $\mathrm{CaF}_{2}$ 中性フラックス $(\mathrm{b})$ 大入熱溶接 用に市販されている $\mathrm{BL}=-1.90$ の高 $\mathrm{SiO}_{2}$ 系酸性フラ ックスを用いた。

\section{3. 試作した MIG +2SAW 溶接機}

試作した $\mathrm{MIG}+2 \mathrm{SAW}$ 溶接機は既設の $3 \mathrm{SAW}$ 溶接 機のL極を容量 $2000 \mathrm{~A}$ の直流トランスに接続できるよ らに改造し，制御盤は MIG と SAW が併用できるよう な副操作箱を設けて収納した. L極の MIG の電源特性 は垂下特性の DGRP である. M極と T極は交流のスコ ット結線にした $2 \mathrm{SAW}$ を極と同一台車に載せて 1 ラ ン溶接する装置である. Fig. 1 は MIG と 2SAWトー チの関係を模式的に示した図である.MIG トーチは 2 重シールド方式 ${ }^{7)}$ とし, 内ガスは $\mathrm{Ar}+\mathrm{CO}_{2}$ の混合比を 1:1 にして, 外ガスおよびアフターシールドは純Ar した.

\section{4. 実 験 結 果}

\subsection{MIG + 2SAW 法と他の溶接法による溶接金属の}

\section{靬性比較}

まず，実験室的に鋼板を用いて，本研究の $\mathrm{MIG}+2$ SAW 法で得られる溶接金属の靱性を従来の 3SAW 法 と比較検討した. Fig. 2 は板厚 $50 \mathrm{~mm}$ の鋼板 $\mathbf{C}$ を用 いて, $\mathrm{MIG}+2 \mathrm{SAW}, 2 \mathrm{SAW}$ の多層溶接および $3 \mathrm{SAW}$ で溶接した時の溶接金属の靱性を示す．溶接材料は全

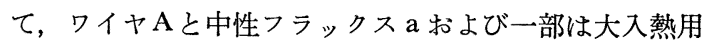
に市販されている酸性フラックス b を用いた．MIG+ $2 \mathrm{SAW}$ 法は $2 \mathrm{SAW}$ 法の内面 1 層, 外面 2 層の溶接法と

Table 1. Relation between welding process and sample No.

\begin{tabular}{|c|c|c|c|c|c|c|}
\hline \multirow{2}{*}{$\begin{array}{c}\text { W. T. } \\
\text { (mm) }\end{array}$} & $\begin{array}{c}\text { Somple } \\
\text { No. }\end{array}$ & \multirow{2}{*}{ Gr. } & & \multicolumn{3}{|c|}{ Welding Process } \\
\cline { 5 - 7 } & & & MIG +2SAW & 2MIG+SAW & 3 SAW \\
\hline \multirow{2}{*}{38} & A & $\times 52$ & Plate & 0 & - & 0 \\
\cline { 2 - 7 } & B & 5 LB & Pipe & - & 0 & 0 \\
\hline \multirow{2}{*}{50} & C & $\times 52$ & Plate & 0 & - & 0 \\
\cline { 2 - 7 } & D & 5 LB & Pipe & - & - & 0 \\
\hline
\end{tabular}

0 : Experimented

Table 2. Welding condition for 3SAW and MIG+2SAW processes.

\begin{tabular}{|c|c|c|c|c|c|c|c|c|c|c|c|c|c|c|}
\hline \multirow{3}{*}{$\begin{array}{l}\text { Process } \\
\text { SSAW }\end{array}$} & \multirow{2}{*}{\multicolumn{2}{|c|}{\begin{tabular}{r|r}
$\begin{array}{r}\text { Elect-Wire } \\
\text { rode } \\
\text { dio } \\
(\mathrm{mm})\end{array}$ \\
\end{tabular}}} & \multirow{3}{*}{\begin{tabular}{|c|}
$\begin{array}{l}\text { Elect- } \\
\text { rode } \\
\text { Angle }\end{array}$ \\
$0^{\circ}$ \\
$15^{\circ}$ \\
$25^{\circ}$
\end{tabular}} & \multirow{3}{*}{\begin{tabular}{|c|}
$\begin{array}{c}\text { Wire } \\
\text { Spacing } \\
(\mathrm{mm})\end{array}$ \\
30 \\
30
\end{tabular}} & \multicolumn{2}{|c|}{ Thickness } & \multicolumn{2}{|c|}{$38 \mathrm{~mm}$} & \multirow[b]{2}{*}{$\begin{array}{l}\text { Heot } \\
\text { Input } \\
(\mathrm{K} N \mathrm{Nom})\end{array}$} & \multicolumn{2}{|c|}{ Thickness } & \multicolumn{2}{|c|}{$50 \mathrm{~mm}$} & \multirow[b]{2}{*}{$\begin{array}{l}\text { Heat } \\
\text { Input } \\
\text { (KN/Cm) }\end{array}$} \\
\hline & & & & & Bevel & $\begin{array}{c}\text { Welding } \\
\text { Current } \\
\text { (A) }\end{array}$ & $\begin{array}{l}\text { Arc } \\
\text { Volfage } \\
\text { (V) }\end{array}$ & $\begin{array}{l}\text { Speed } \\
(\mathrm{mm} / \mathrm{min})\end{array}$ & & Bevel & $\begin{array}{l}\text { Welding } \\
\text { Current } \\
\text { (A) }\end{array}$ & $\begin{array}{l}\text { Arc } \\
\text { Volroge } \\
\text { (V) }\end{array}$ & $\begin{array}{l}\text { Speed } \\
\mathrm{mm} / \mathrm{min}\end{array}$ & \\
\hline & $\begin{array}{l}1 \\
2 \\
3\end{array}$ & $\begin{array}{l}4.8 \\
4.8 \\
4.8\end{array}$ & & & $3 8 \longdiv { \frac { 1 3 } { 1 2 } }$ & $\begin{array}{r}1200 \\
880 \\
760\end{array}$ & $\begin{array}{l}37 \\
40 \\
43\end{array}$ & 550 & 122.5 & $5 0 \longdiv { \frac { 1 8 } { 1 2 } }$ & $\begin{array}{r}1200 \\
880 \\
760\end{array}$ & $\begin{array}{l}37 \\
40 \\
43\end{array}$ & 300 & 224.5 \\
\hline MIG + 2SAW & $\begin{array}{l}1 \\
2 \\
3\end{array}$ & $\begin{array}{l}4.8 \\
4.8 \\
4.8\end{array}$ & $\begin{array}{r}12^{\circ} \\
5^{\circ} \\
15^{\circ}\end{array}$ & $\begin{array}{r}380 \\
18\end{array}$ & $38 \frac{16}{6}_{\frac{6}{16}}^{30}$ & $\begin{array}{r}950 \\
1000 \\
850\end{array}$ & $\begin{array}{l}29 \\
35 \\
41\end{array}$ & 500 & $\begin{array}{c}33.1 \\
+ \\
83.8\end{array}$ & $50 \frac{21}{8}_{27^{\circ}}^{27^{\circ}}$ & $\begin{array}{r}950 \\
1100 \\
900\end{array}$ & $\begin{array}{l}29 \\
35 \\
41\end{array}$ & 300 & $\begin{array}{c}55.1 \\
+ \\
150.8\end{array}$ \\
\hline
\end{tabular}

Note. MIG gas condition 1) Inner shield : Ar $40 \mathrm{l} / \mathrm{min}+\mathrm{CO}_{2} 40 \mathrm{l} / \mathrm{min}$ 2) Outer shield : Ar $50 \mathrm{l} / \mathrm{min}$ 3) After shield : Ar $50 \mathrm{l} / \mathrm{min}$ 


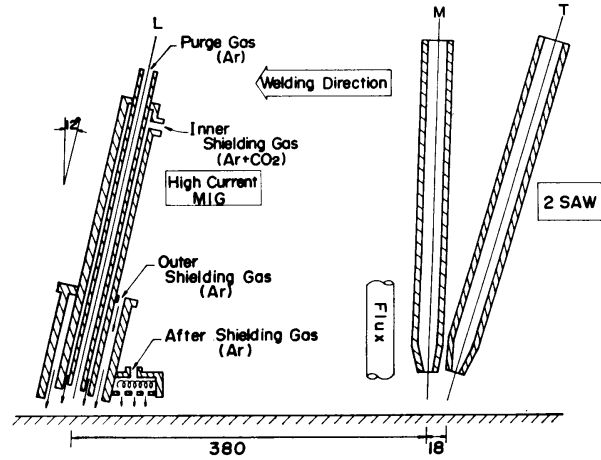

Fig. 1. Schematic diagram of $M I G+2 S A W$ process.

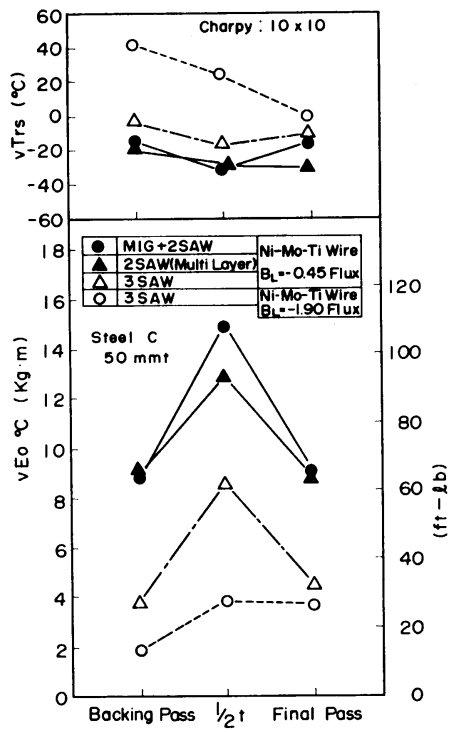

Fig. 2. Toughness of weld metal in $M I G+2 S A W$ and other SAW processes.

同程度の靱性を示すが, 能率上の観点から 1 ランで溶接 できるMIG+2SAW 法の方が有利である. 3SAW の溶 接金属の靶性は MIG+2SAW 法および $2 \mathrm{SAW}$ 法の多層 溶接よりも劣化している. 更にフラックスを酸性のbに した場合の溶接金属の靱性は酸素含有量 $(550 \mathrm{ppm} \sim 650$ $\mathrm{ppm})$ の増加によつて著しく劣化することが認められる. 次に工場で管厚 $38 \mathrm{~mm}$ の鋼管を用いて, $2 \mathrm{MIG}+\mathrm{SAW}$ 溶接を行い, 溶接金属の靱性を $3 \mathrm{SAW}$ 法と比較した. Fig. 3 は管厚 $38 \mathrm{~mm}$ の鋼管Bを用いて，2MIG $+\mathrm{SAW}$ の組み合わせで溶接した場合の溶接金属の靱性を示す. 2MIG にして MIG 溶着部分を増すことによつて板厚中 央の溶接金属は $3 \mathrm{SAW}$ に比べて著しい高勒性が得られ るが，内面側と外面側の溶接金属の靶性は $3 \mathrm{SAW}$ の れと同等である。

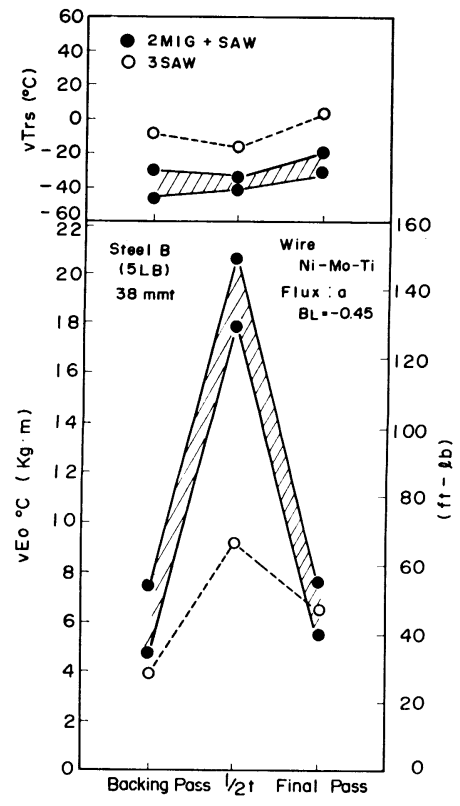

Fig. 3. Effect of welding process on toughness of weld metal.

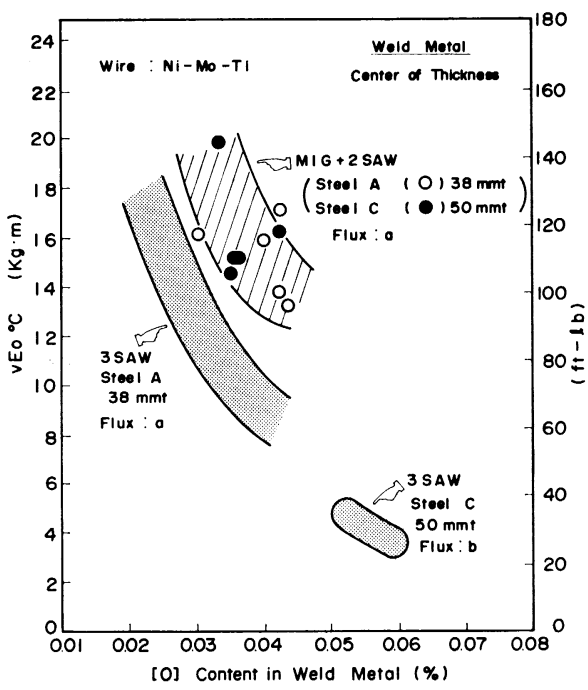

Fig. 4. Effect of $[\mathrm{O}]$ content on toughness of weld metal.

\subsection{MIG +2SAW 法および 3SAW における溶接金属 の靶性におよぼす酸素の影響}

Fig. 4 は鋼板A と Cを用いた $\mathrm{MIG}+2 \mathrm{SAW}$ 法の酸 素含有量と溶接金属の勒性の関係を従来の 3SAW と比 較検討した結果である. 従来から溶接金属の酸素含有量 が 200ppm 以上でかつ高い程, 勒性が劣化することが明 らかになつている8)9). しかし今回フラックス $\mathrm{a}$ を用いた 
$\mathrm{MIG}+2 \mathrm{SAW}$ 法と $3 \mathrm{SAW}$ 法の酸素含有量は $280 \sim 430$ $\mathrm{ppm}$ の範囲で同程度であるにもかかわらず,同一鋼板と 同一溶接材料に拈いて, MIG + 2SAW 法は 3SAW より も良好な靱性值を示す.この理由は, 後述するが, MIG $+2 \mathrm{SAW}$ 法の方が $3 \mathrm{SAW} よ り も$, 粗大の初折フェライ トが少ないことによるものである. 大入熱用の酸性フラ ックスbを用いた $3 \mathrm{SAW}$ の酸素含有量は 550〜630 ppm と多量になるため, 溶接金属の鞋性の低下が大きいこと を認めた.この結果から厚肉溶接の場合における MIG $+2 \mathrm{SAW}$ 法は $3 \mathrm{SAW}$ を用いるよりも, 同一酸素含有量 に拈いて，得られる靱性は高く良好な方法といえる.

\subsection{MIG +2SAW 法と 3SAW の HAZ 靭性比較}

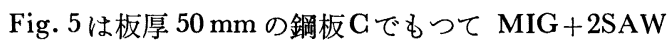
法と 3SAW 法に拈ける板厚中央から採つた HAZ 靱性 の比較を示す. 3SAW は HAZ の脆化が顕著であるが， $\mathrm{MIG}+2 \mathrm{SAW}$ 法の $\mathrm{HAZ}$ は脆化の度合が少なく良好で

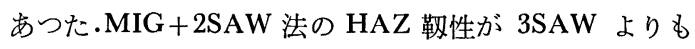
良好な理由は, 5.1 項で詳述するごとく, HAZ の受け る熱サイクルの状態が異なること，およびビード形状の 差に起因する. 板厚 $38 \mathrm{~mm}$ の 鋼板 $\mathrm{A}$ の場合において ๖, $\mathrm{MIG}+2 \mathrm{SAW}$ 法の板厚中央の $\mathrm{HAZ}$ の靱性は $3 \mathrm{SAW}$ 法よりも約 $50 \%$ 高い吸収エネルギを示す事が認められ

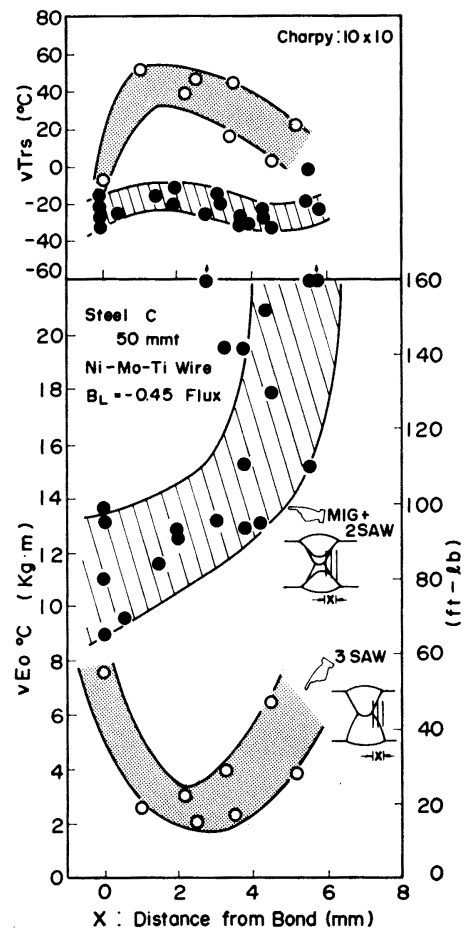

Fig. 5. Toughness of $\mathrm{HAZ}$ in $\mathrm{MIG}+2 \mathrm{SAW}$ and $3 \mathrm{SAW}$ process.
た.このように, MIG+2SAW 溶接法の方が板厚中央に 扣いて, 3SAW よりも HAZ 鞀性は良好であることがわ かつたので, 次に HAZ の靶性におよぼす板厚方向の影 響について検討した. $\mathrm{MIG}+2 \mathrm{SAW}$ 法の溶接金属のす ベてがS AW に相当する板厚の外面側および内面側から サンプリングした HAZ の鞋性を $3 \mathrm{SAW}$ の HAZ 靱性 と比較した.Fig. 6 は板厚 $38 \mathrm{~mm}$ と $50 \mathrm{~mm}$ の鋼板A と Gを用いて，フラックス aで $\mathrm{MIG}+2 \mathrm{SAW}$ 法と $3 \mathrm{SAW}$ で溶接した時のファイナルパス側の HAZ とバッキング パス側から試料採取した場合の靶性の比較を示す. 図か らわかるように MIG+2SAW 法の HAZ 靱性は 3SAW のそれと同等以上の靱性を示した. また両溶接法ともに バッキングパス側から試料採取した HAZ の靱性は, フ ァイナルパスの熱サイクルを受けることによつて, ファ イナルパス側から試料採取した場合よりも HAZ 靶性は やや良好である.

\section{5. 考察}

\subsection{MIG +2SAW 法の熱サイクルおよび溶接金属と HAZ の顕微鏡組織}

板厚 $38 \mathrm{~mm}$ の鋼板Aを用いて, MIG と $2 \mathrm{SAW}$ の極 間距離を $380 \mathrm{~mm}$ に離した場合の $\mathrm{MIG}+2 \mathrm{SAW}$ 法のボ ンド部の熱サイクルと通常の 3SAW の熱サイクルを比 較した結果を Fig. 7 に示す. 測定は図中に示すよら に, V溝開先をとつた鋼板の裏面からドリルホールをあ けて, MIG のボンド部を測温しらるようにした・MIG+

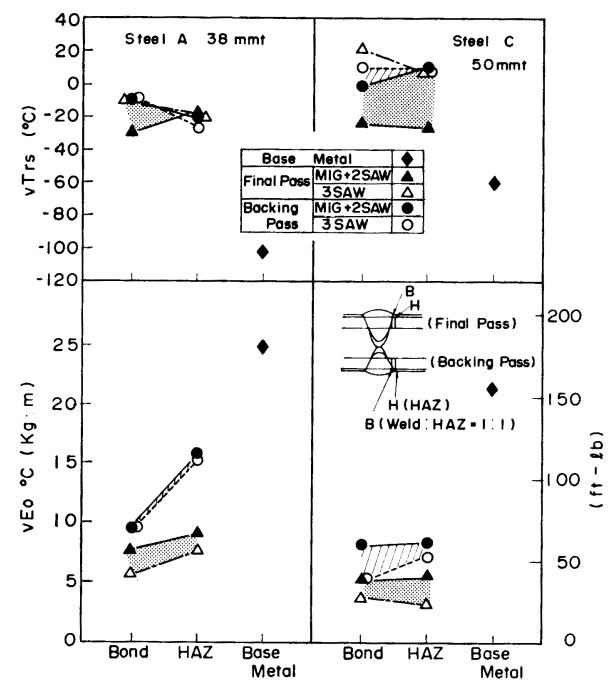

Fig. 6. Effect of through-thickness direction on toughness of $\mathrm{HAZ}$ in MIG $+2 \mathrm{SAW}$ and $3 \mathrm{SAW}$ process. 


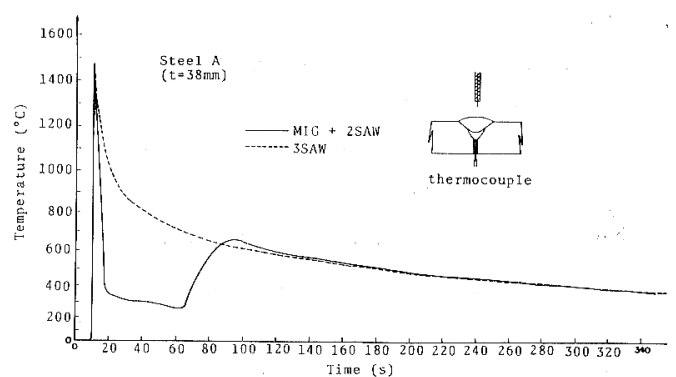

Fig. 7. Heat cycle pattern of MIG +2SAW and 3SAW processes.

2SAW 法は溶接金属々 HAZ の組織が粗大化して靱性 劣化を起こす約 $1000^{\circ} \mathrm{G}$ 以上の加熱時間が，3SAWより も半分以下に減少していることが認められ，溶接入熱を 分散し， 1 溶融池当たりの入熱を小さくすることができ る.またL極の MIGビードが Ar 変態点以下に泠却さ

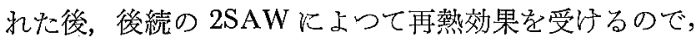
鞀性に対して有效に作用与ることがわかつた．Photo. 1 は板厚 $50 \mathrm{~mm}$ の鍋板 $\mathrm{C}$ を $\mathrm{MIG}+2 \mathrm{SAW}$ 法と $3 \mathrm{SAW}$ 法で溶接した時の顕微鏡組織を比較して示した結果で ある. MIG+2SAW 法の SAW 溶接金属部分末うび板 厚中央の MIG 溶着部分は溶接入熱を分散し 1 溶融池当 たりの入熱を小さくすることができるので, 3SAW 溶 接金属部分よりも粗大フェライト量が少なく，大部分ア シュキラーフェライトになつて扣り，このような組織は 溶接金属の䩲性に対して良好であることが明らかたされ
ている10)11), HAZ に関しても MIG 溶着部分の HAZ 粗粒域は後続の $2 \mathrm{SAW}$ によって, 再度 $\mathrm{Ac}_{3}$ 点以上に加 熱されるために，HAZ 細粒域と同じく，大部分がアシ ュキラーフェライト化している. 外面側のSAWの HAZ 粗粒域は両溶接法ともに, 同様の組織を示して和り,大部 分上部ベイナイトはなているのが羿められる. Photo. 2 は管厚 $38 \mathrm{~mm}$ の鋼管 $\mathrm{B}$ と板厚 $50 \mathrm{~mm}$ の鋼板 $\mathrm{G}$ の $\mathrm{MIG}+\mathrm{SAW}$ 溶接法和よび $50 \mathrm{~mm}$ の鋼管Dの $3 \mathrm{SAW}$ 法のマクロ組織を示す．溶融型フラックスaを用いて管 厚 $50 \mathrm{~mm}$ の鋼管Dを $3 \mathrm{SAW}$ したビード形状は, バッ キングパスの波目が荒いのに対して, 板厚 $50 \mathrm{~mm}$ の鋼板 Gを MIG+2SAW 法で溶接した場合は良好なビード形

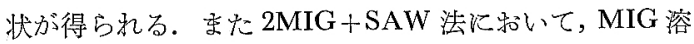
着部分を増した鋼管 Bのビード形状はマッシュルーム状 のビードになる．また板厚 $50 \mathrm{~mm}$ の鋼管をSAW 法で 入熱制限をして，内面 1 層，外面 2 層の積層で溶接した 場合はマクロ形状が良好となるが，能率の低下が大き い.このよらにマクロ形状の結果からしても，板厚 50 $\mathrm{mm}$ の溶接を対象とする場合火は， $\mathrm{MIG}+2 \mathrm{SAW}$ 法が 最適であると考える・

\section{$5.2 \mathrm{MIG}+2 \mathrm{SAW}$ 法と 3SAW 法の溶融速度とフラッ} クス消費量の比較

$\mathrm{MIG}+2 \mathrm{SAW}$ 法のワイヤの溶融速度とフラックス消 費量について検討した結果を 3SAW のとれと比較し た.Fig. 8 は MIG+2SAW 法と 3SAW 法の電流和 と溶融速度の関係を示す。 ハッチング部分はすでに明ら
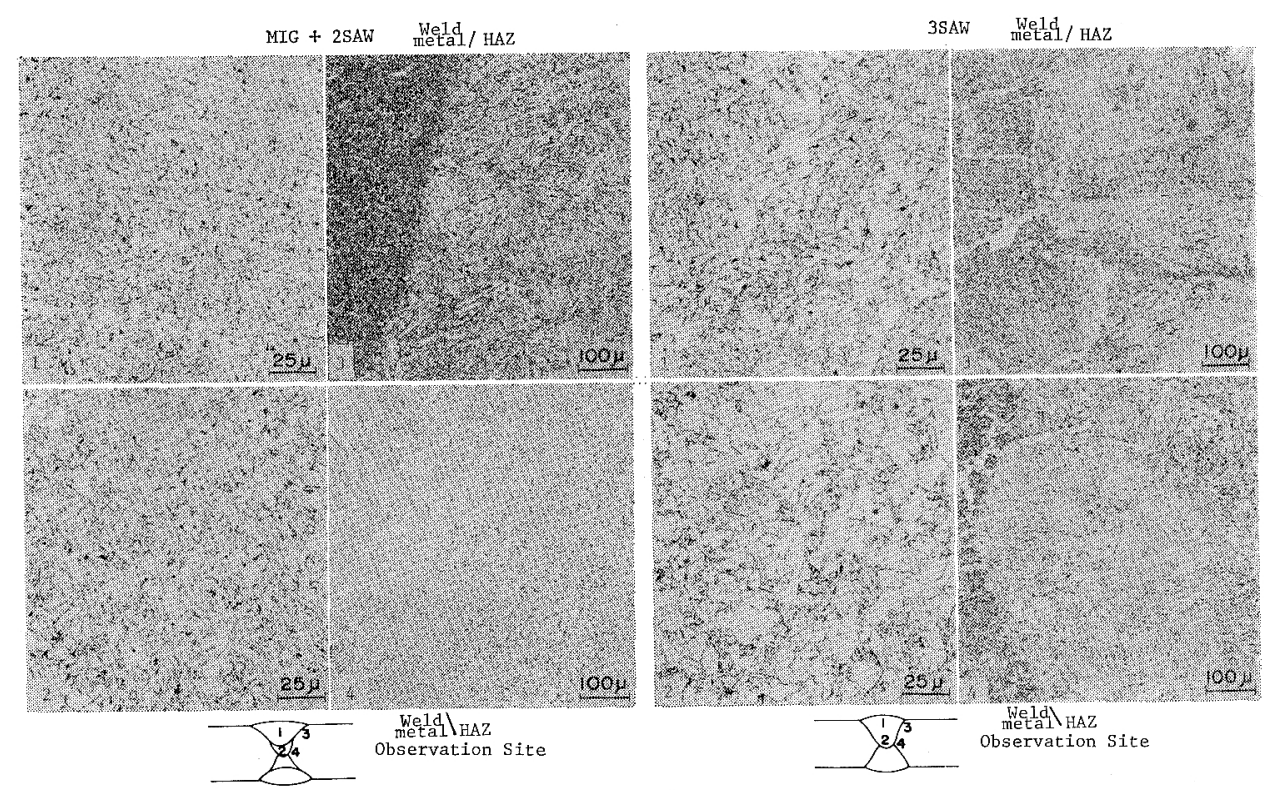

Photo. 1. Micro-structures of welded joint in MIG +2SAW and 3SAW processes. (Steel C) 
2MIG + SAW Steel B, 38mmt

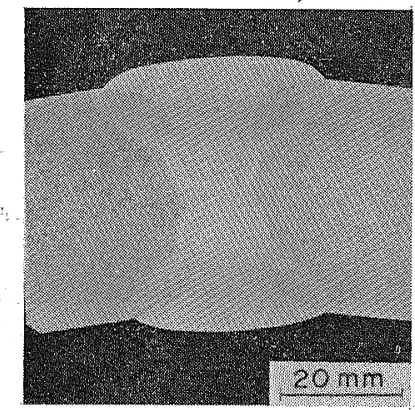

MIG + 2SAW Stee1 C, 50mmt 3SAW Stee1 D, 50mmt

Photo. 2. Macro-structures of welded joint in MIG+SAW and 3SAW processes.

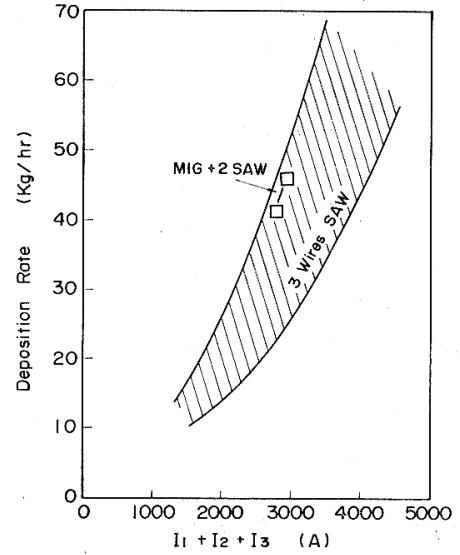

Fig. 8. Relation between sum of current and deposition rate.

がした ${ }^{12)} 3 \mathrm{SAW}$ 法の 電流和とワイヤの溶融速度の関 係である.この図に MIG+2SAW 法の溶融速度をプロ ットした結果は，同一電流に拈いて,3SAW 法の範囲の 上限近くにあり, MIG+2SAW 法は 3SAW 法と比べて 同等以上である。こ扎はラックスを溶融するのほ必要 な垤量が少なく熱効率が良好であるためによるものと考 える ${ }^{13)}$.Fig. 9 は溶接入熱とフラックス消費量の関係を $\mathrm{MIG}+2 \mathrm{SAW}$ 法と 3SAW 法を比較して示す.同一入熱 で比較した場合, MIG+2SAW 法は 3SAW 法よりもフ ラックスの消費量が少なく, $2 \mathrm{SAW}$ 法の外々ら上に位置 している.こ机はL極が MIGであり，SAW の電極数 が 2 極であることにより SAW に和ける入熱は 3SAW に比べて低入熱になるので，溶融スラグの過熱が生じ ず，シールド機能の低下も少ない，このために，溶融型 フラックスに拈いても，Photo. 2 飞示したように，板 厚 $50 \mathrm{~mm}$ の $\mathrm{MIG}+2 \mathrm{SAW}$ 法による溶接ビードは滑ら かである。

\section{$5.3 \mathrm{MIG}+2 \mathrm{SAW}$ 溶接法のアーク現象}

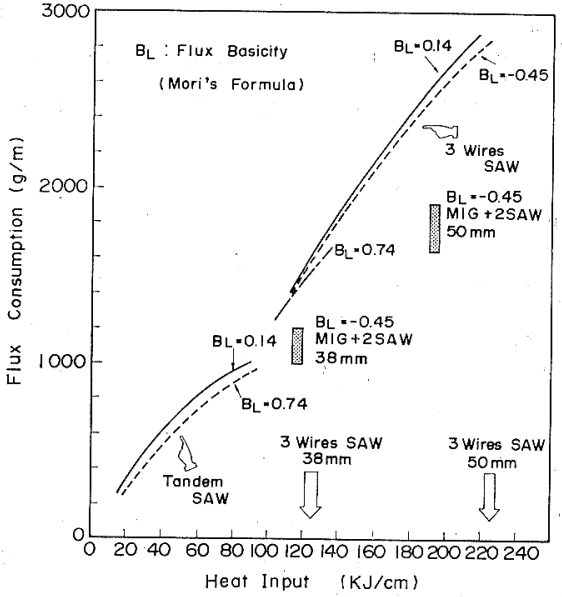

Fig. 9. Relation between heat input and flux consumption.

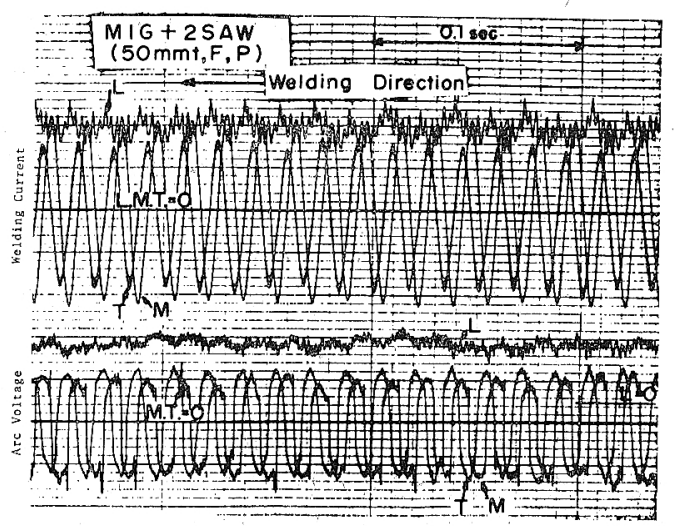

Fig. 10. Oscillogram of welding current and arc voltage in MIG+2SAW process. (Steel C)

大電流 MIG 自身を 2 電極または 3 電極でるつて, UOE 鋼管溶接に適用する場合，溶接電流，アース位 置，電極間の相互干渉和よび鋼管自身の磁化によつて, 
アークの偏向を受ける事が明らかになつており，種々の 対策を講じる必要がある5)14). Fig. 10 は板厚 $50 \mathrm{~mm}$ の 鋼板 Cを MIG+2SAW 法でもつてファイナルパス溶接 した時の溶接電流とアーク電圧を電磁オシログラフで測 定した結果を示す.アース位置は開始端である.MIG と $\mathrm{SAW}$ のトーチ間隔を $380 \mathrm{~mm}$ 離したこととSAW は交 流であるために，L極の MIG 溶接はアークの相互干渉 が少ないので，正常なスプレー移行を得ることができ， グロビュールおよび短絡移行は認められない，M極と T 極をスコット結線にした交流の $2 \mathrm{SAW}$ のアーク現象に 関しても，溶接電流とアーク電圧の振れは小さく良好で あり, 通常の $2 \mathrm{SAW}$ と何ら遜色はなかつた.

以上述べた事柄から本方法の $\mathrm{MIG}+2 \mathrm{SAW}$ 法は厚肉 鋼管の溶接に対して良好な溶接方法であることがわかつ たので，大径管工場の溶接機に適用することを検討して いる.

\section{6. 結 言}

溶接プロセスの面から板厚 $38 \mathrm{~mm}$ と $50 \mathrm{~mm}$ を対象 とした厚肉鋼管制造のための溶接法として, 大電流MIG $+2 \mathrm{SAW}$ 法について検討を行い，本方法による溶接継手 の性能を 3SAW と比較して, 次の事柄を明らかにした.

（1）試作した MIG+2SAW 溶接機は L 極を

DGRP にして， M極と T極は交流のスコット結線にし た $2 \mathrm{SAW}$ を極と同一台車に載せて 1 ラン溶接する装 置である.MIG と SAW のトーチ間隔は約 $350 \mathrm{~mm}$ 以上 離したことと SAW は交流であるために，アークの相互 干渉は緩慢であつた。

（2）本溶接装置によるワイヤの溶融速 度は 3SAW 法の同一電流和で比較した場合，同等以上であり，それ はフラックスを溶融するのに必要な熱量が少なく熱効率 が良好なためによるものである。 また本方法は同一入熱 において, 3SAW よりもフラックスの消費量は少ない。 従つてスラグの過熱によるシールド機能の低下を招かな いので, 溶融型フラックスにおいても, $50 \mathrm{~mm}$ 厚の溶接 ビードは健全で滑らかである.

(3) MIG + 2SAW 法は MIG と SAW の極間距離 が十分に長く，2 溶融池でもつて溶接されるため，溶接 入熱を分散し，1 溶融池当たりの入熱を低下して溶接金 属の粗大フェライトの生成を抑制することができる．ま たこの溶接法は，溶接金属と HAZ の組織が粗大化して
靫性劣化を起こす約 $1000^{\circ} \mathrm{C}$ 以上の加熱時間が $3 \mathrm{SAW}$ に比べて半分以下にできること，及びL極 MIG ビード が $\mathrm{Ar}_{1}$ 変態点以下に冷却されたのち, 後続の $2 \mathrm{SAW} に$ よる再熱効果が靯性に有効作用することがわかつた。

（4）鋼板表層寄りのシャルピーテストにおける $\mathrm{MIG}+2 \mathrm{SAW}$ 法の溶接金属の勒性は $3 \mathrm{SAW}$ 之同等以上 であるが， MIG + 2SAW 法の板厚中央の靱性は 3SAW の勒性よりも優れており，2SAW の多層溶接金属と同等 である。また $2 \mathrm{MIG}+\mathrm{SAW}$ 法にして, MIG 溶着部分を 増すと，板厚中央で著しい高靯性が得られる。

（5） HAZ の勒性は MIG+2SAW 法の方が $3 \mathrm{SAW}$ よりも高勒性が得られる・そのらちすべてが SAW 溶接 金属に相当する板厚の外面側，内面側から試料採取した $\mathrm{HAZ}$ についても，MIG + 2SAW 法は 3SAW と同等以 上の勒性を示し， MIG に相当する板厚中央に打汀る $\mathrm{HAZ}$ は $3 \mathrm{SAW}$ の板厚中央よりも極めて良好な靫性が 得られる.

\section{交献}

1 ) 平林清照, 平 忠明, 市之瀬弘之：溶接学会誌, 50 (1981) 4, p. 63

2 ) 高木乙磨：溶接学会誌， 13 (1962) 6, p. 452

3 ) 藤森成夫, 斎藤 亨, 大谷幸三郎, 矢竹 丘, 長 谷泰治, 常富栄一：溶接学会講演概要 (1979) 24 , S 166

4 ) 上垣達交, 美浦一彦, 小西博典, 歌橋千之, 他: 溶接学会講演概要 (1979) 25，S 276

5 ) G. Tanaka and $I$. Watanabe: Metal Construction, 9 (1977) 3, p. 114

6 ) 森 一美: 鉄と鋼, 46(1960), p. 466

7 ) 越賀戻夫, 田中甚吉, 渡辺之: 溶接学会講演概 要, (1975) $16, \mathrm{~S} 136$

8 ) 伊藤慶典, 中西睦夫: 第 69 回溶接学会溶接法研 究委員会資料

$9) \quad K$. Hirabayashi, $T$. Taira, $T$. Yamagughi and $K$. TAKEShige: IIW-Doc. XII-A-135-77

10) 山口哲夫, 平 忠明, 平林清照: 溶接学会誌, 46 (1977) 9 , p. 48

11）平 忠明, 平林清照, 大須賀立美, 五代友和：溶 接学会誌，46 (1977) 11，p. 14

12）平林清照, 平 忠明, 市之瀬弘之：溶接学会誌投 稿中

13）平林清照，赤尾一孝，平 忠明，市之瀬弘之：日 本溶接協会, 第 33 回プラズマ分科会資料

14）渡辺之，鈴木元昭，平野攻：鉄之鋼，65 (1979) 4, S 283 